\title{
Impact of government size and corruption on economic growth
}

\author{
NedraBaklouti *, Younes Boujelbene \\ Unit of Research in Applied Economics (URECA); Faculty of Economics and Management, University of SFAX, Tunisia \\ *Corresponding author E-mail:nedra.baklouti@mail.com
}

\begin{abstract}
This paper examines the role of government in economic growth by extending the neoclassical production-function by incorporating two dimensions of government such as, the size and quality. The size is measured by general government final consumption expenditures. The quality of governance is measured by the index of perception of corruption which is being tested in 12 countries in the MENA region in the period between 1998 and 2011. Our empirical results indicate that when the public sector is "too big", economic growth is negatively affected and that the relationship between corruption and economic growth is significantly negative with the bad effects of this phenomenon that include a loss of revenue for the state in the benefit of the individual, the increased costs related to the conduct of the affairs of the state, an inefficient use of public spending and stifling economic growth in the region. We argued then, that investments in the capacity which strengthened governance are a priority for improving the growth of the countries examined.
\end{abstract}

Keywords: Corruption; Government Size; Economic Growth; MENA Countries.

\section{Introduction}

The process of economic growth and its determinants are a topic of interest for both the theoretical and the empirical research. The interest is mainly justified not only by observing the rising standard of living over time, but also by the existence of large differences in the living standards between countries. The process of economic growth can be considered to improve the quality of life indicators through more efficient use of economic resources. Economic growth is achieved through the specific indicators related to the gross domestic product (GDP), for example by increasing the per capita GDP or the growth rate of the real GDP.

On the one hand, the relationship between government size and economic growth has a big debate. The size of government can be seen as the degree of state intervention to correct the market failures. The excessive intervention may lead to the failure of the government which is detrimental to economic growth. Similarly, the size of government can be approximated by spending bureaucrats such as wages. At our study, we took the final consumption of expenditure of government as a proxy for the size of government. Economic theory recognized the public spending as the engine of economic growth. Lucas (1988) argues that the public spending in education increases the level of human capital, which contributes to the knowledge-based on the economic growth Zagler and Dürnecker (2003) argued that the instruments of the fiscal policy, such as government spending on education, the public infrastructure, research and development, and health have long term effects on the economy of the country.

Recognizing the importance of the public spending, taxpayers demand an efficient use of the public spending. The effectiveness of the public expenditure is defined as the government's ability to maximize its economic activities. Therefore, the efficiency of public spending could be used as an indicator to assess the effectiveness of the implementation of government policy on the ad- ministration, education, health, income distribution and economic stability. It is crucial for the government to spend money collected from taxpayers effectively, because it is accountable to its citizens. In this context, the notion of efficiency provides an assessment of the allocation of resources in promoting the economic growth of a country. At the international level, we agree more that a sound policy and an institutional framework are essential for the economic and the social development. Some authors have shown that countries with low levels of the public spending which is relative to the GDP tend to achieve better efficiency especially for the developing countries (Afonso et al. 2003). In particular, we show that these are not the countries that spend the most, but that are necessarily the most efficient in the delivery of the public services that are supposed to their funding.

On the other hand, corruption is considered as a theft of public funds from the release of bribes to officials and a wide range of bad economic and political practices in which business men, politicians and bureaucrats get richer. An example of corruption includes the sale of state assets by the public officials, the corruption and the embezzlement of the public funds. In fact, there are two different views about the relationship between corruption and economic growth which is empirically controversial. For some empirical studies as (Mauro, 1995, Treisman, 2000; Lu, 2001; Ahlin and Pang, 2008), show that corruption reduced the economic growth, whereas the others such as (Ehrlich and Lui, 1999; Aidt, Dutta and Sena, 2008; Huynh and Jachochavez, 2009) think that the higher level of corruption does not necessarily slow growth. For example, Aidt et al. (2008) provides that in cases where corruption reduces paper work, we do not find a significant relationship between corruption and economic growth. Acemoglu and Verdier (2000), show that corruption is among the failures of the contribution of the state. For this, higher wages are needed to prevent the samples of bribes by the bureaucrats to reduce corruption. In this way, the relationship between the size of government and 
its inefficiency, namely, corruption has been a major topic in the economy.

In a race to explain the ambiguous results, this study examines both the effect of the size of government and the other of corruption on the economic growth. We are using the annual data from 12 countries in the MENA region, between 1998 and 2011.

\section{Literature Review}

Many empirical studies have tested the predictions of the theory of endogenous growth, as it provides governments with a theoretical basis for an active participation in the process of growth in the developing economies (see Brunetti et al. 2003, Fatas et al, 2003; Hughes-Hallett et al, 2004; Gali and Perotti, 2003 and Suleiman, 2010). These studies have been stimulated by the need to have a better understanding of the nature of the relationship between public spending and economic growth and therefore, a better understanding of the issues related to the increase in public spending in the short, medium and long term.

Today, governments have a crucial role in the economic growth of the developing-countries. In this regard, extensive studies have been done on the impact of the size of government and government spending on the economic growth. To this extent, Suleiman (2009) observed that the size of government and its impact on growth has emerged as a major problem of budget management for the transition of economies.

He noted that the previous researches focused mainly on the size of government in industrialized countries, but given the opening of most developing countries (DCs), trade dependence, the vulnerability to external shocks and the volatility of finance, the role and the size of government programs become relevant for stabilization and adjustment. Mitchell (2005) argued that the large and the growing government are not conducive to better economic performance. The literature also shows mixed results regarding the relationship between the size of government and economic development.

First, the size of government can slower the economic growth due to government inefficiency, to the excessive tax burden, to the distortion systems and to the stimulating interventions foreclosing the market to the economy (Barro, 1991; Bajo-Rubio, 2000). For example, Landau (1986) reviewed the impact of consumption spending on economic growth. He concluded that consumption spending of government have a significant negative effect on economic growth.

In addition, Tanzi and Zee ( 1997) find a negative impact on the size of government which exceeds a certain threshold and the reasoning behind this argument is that in countries with large governments, the share of public expenditure in the private sector on productivity is generally smaller than in countries with small governments (Folster and Henrekson , 2001). Then Abu- Bader and Abu-Gharn (2003) showed that the government spending had a negative effect on the economic growth of these countries Egypt, Syria and America. Chen and Lee (2005) using time series data for the period between 2003 and 1979 for Taiwan showed the nonlinear-relationship between the government size and the economic growth. Also Guseh (1997) presents a model that differentiates the effects of government size on economic growth through political systems in the developing countries. The growth of government size has negative effects on the economic growth, but the negative effects are three times greater in non-democratic systems. Indeed, several studies than the democratic ones. Have shown that we can increase the efficiency of government's spending, either by providing all services with fewer resources or by using the existing levels of spending more effectively (see Afonso et al. 2011). Second, the government activities may also have positive effects on the beneficial externalities, the development of the infrastructure and the legal, the administrative and the economic interventions to compensate for the market failures (Ghali, 1998 Dalagamas, 2000). In a theoretical framework, Ram (1986) show that the total effect of government's spending on economic growth was positive in all cases (except for a few countries). Similarly, Komain et al (2007), using the Granger causality test, examined the relationship between the public spending and economic growth in Thailand; it was found that public spending and economic growth are not co- integrated. The result also suggested that the relationship is unidirectional having a positive and a significant effect of the public spending on economic growth.

In this article, we examine a vast literature on the subject which further benefits the debate. The focus is on the most recent documents that deal with the relationship between government size and the economic growth. The most recent studies generally show a negative correlation between the government size and economic growth.

Our motivation comes from the study of Cooray (2009) who used an econometric model that includes the government spending and the quality of governance in a cross-sectional study of 71 countries The results showed that the size and the quality of governance is positively correlated with economic growth. The dimensional size as measured by public investment, has been integrated into the work of Barro (1991), Barro and Sala -i- Martin (1992), Easterly and Rebelo (1993), Devarajan, Swaroop and Zou (1996), Hulton (1996), Pritchett (1996), Aschauer (2000). However, much more attention has been paid to the quality dimension that emphasizes the efficient provision of public goods. Hulton (1996), Pritchett (1996) and Aschauer (2000) examined the effectiveness of public capital in the growth process. This study differs from the studies of Hulton, Pritchett and Aschauer in the quality of government which is measured by the index of perception of corruption, built by the non-governmental organization "Transparency International".

Corruption has significant influences on many aspects of societies (Lambsdorff, 2006). Here we provide a brief literature review on the influence of corruption in these sub- areas of the economic development. Economic growth is a key element of economic development. Economic growth continues to improve the standard of living of the population by increasing both private income and social services. In some cases, poor countries can achieve economic growth without development. However, no country can support economic development without growth. It is therefore important to study the impact of corruption on the economic growth when we study the relationship between corruption and the economic development.

Indeed, there is a theoretical discussion of the effect of corruption on economic growth. Some authors point out that corruption can promote the economic growth (" grease the wheels "). Leff (1964) and Huntington (1968) argue that bribes can be used as an instrument of incitement to influence public officials, leading to an improvement in the quality of the civil services. Lui (1985) also shows in his model that bribes can effectively speed up the bureaucratic process. However, you can criticize the officials who have an incentive to delay operations that extract higher payments (see Rose- Ackerman, 1997). Other researchers point out that corruption reduces the economic growth ("Sand in the wheels"). For example, Murphy, Shleifer and Vishny (1991) point out that in corrupt societies, the most talented people are allocated in rentseeking rather than those of production. So the research of unproductive rent, lower the economic growth, as they have made positive returns only for rent seekers instead of the whole society (Krueger, 1974). From a different angle, Shleifer and Vishny (1993) reported that the corrupted officials can distort the investment projects to those with better opportunities for corruption. In other words, the corrupted bureaucracy will not provide services to the most efficient producers, but the producer who has the biggest bribes. In general, most empirical studies confirm a negative association between corruption and economic growth.

In this perspective, Ugur and Dasgupta (2011) have used the metaanalysis; mentioning the negative impact of corruption on economic growth. However, they recognize that the indirect harmful effects outweigh the direct ones. This negative view of corruption is supported by the econometric analysis conducted by Mauro, (1995) which shows that corruption retards growth and reduces 
investment. Such consequences justify the change of good governance (Seligson, 2002). In addition, Mo (2001) reports that by means of political instability, the level of human capital and the share of private investment, corruption hinders the economic growth significantly. Pellegrini and Gerlagh (2004) also provide the evidence that corruption reduces the economic growth through its effect on investment and trade policy. Recently, a number of studies indicate that the correlation between corruption and growth is dependent on the quality of institutions. Meon and Sekkat (2005) found that corruption depresses the economic growth, particularly in countries with low quality of governance. However, Aidt et al (2008) also found that in countries with high quality institutions, corruption has a negative impact on growth and, conversely, growth reduces corruption. While in countries with low-quality institutions, corruption has no effect on growth. In addition, Meon and Weill (2010) provide an empirical evidence using the panel of the 54 countries that corruption is beneficial (or at least less harmful) in countries where institutions are weak. These documents provide indirect evidence supporting the hypothesis "grease the wheels" (Aidt, 2009). In addition, a recent study by De Vaal and Ebben (2011) has developed a theoretical model that considers the role of institutions in determining the effects of corruption on economic growth. Their results provide theoretical evidence that the overall effect of corruption on economic growth is highly dependent on the institutional framework of a country. Especially in situations where institutions are not well developed, corruption can be conducive to economic growth. Developed by (De Vall and Ebben 2011) the theoretical model supports the hypothesis of "grease the wheels". In fact, they show that in situations where institutions are not well developed, corruption can be conductive to economic growth.

According to the economic theory, human capital plays a very important role in economic growth (Denison, 1962, Lucas, 1988 Romer, 1986, Schultz, 1961). Among the most important components of the human capital, there is education for this large growth literature linking it to growth (Mankiw, Romer and Weil, 1992, Mulligan and Sala-i-Martin, 1992). Many empirical studies have found a positive relationship between growth and education (Barro, 1991; Levine \&Renelt, 1992, Mankiw et al, 1992); although some recent studies have shown that this relationship is weak (Benhabib and Spiegel 1994; Islam, 1995; Pritchett, 2001).

\section{Data and econometric methodology}

\subsection{Model}

The basic model is an adaptation of the neoclassical production function that was based on the growth model of Mankiw et al. (1992), Knight et al. (1993), Ghra and Hadjmichael (1996), Demetriades and Law (2006). A saving described by the set of the production function is homogeneous at the first degree, so it is derived as follows:

$\mathrm{Y}(\mathrm{t})=\mathrm{F}[\mathrm{H}(\mathrm{t}), \mathrm{K}(\mathrm{t}), \mathrm{A}(\mathrm{t}) \mathrm{L}(\mathrm{t})]$

Where $\mathrm{Y}$ is the real income, $\mathrm{H}, \mathrm{K}$ and $\mathrm{L}$ denote respectively, the human capital, the capital stock and labor force, and A ( $t$ ) is the technological level of the economy.

Following the example of the work of the authors mentioned above, our starting point is the Cobb-Douglass production function of the general form:

$\mathrm{Y}_{\mathrm{t}}=\mathrm{K}_{\mathrm{t}}^{\alpha} \mathrm{H}\left(\mathrm{A}_{\mathrm{t}} \mathrm{L}_{\mathrm{t}}\right)^{-\alpha}$

There is no explicit place for the government or the public sector in the Solow model as described above. However, in many respects, the role of the public sector is very important in economic development. In developing countries or least developed such as the countries of the MENA region, the role of government in the distribution and the allocation of resources are very important. The public sector has externalities on production available by taxes coming to the private income prices for the private producers. Moreover, in the early stage of development, the public sector often plays the key role as the engine of the economic growth. Referring to Arrow and Kurz (1970) and Barro (1991), the public sector can be incorporated directly into the production function as follows:

$$
\begin{aligned}
Y(t) & =F[(K(t), H(t), G(t), A(t) L(t)] \\
& =K_{t}^{\alpha} H_{t}^{\beta} G_{t}^{\gamma}\left(A_{t} L_{t}\right)^{1-\alpha-\beta-\gamma} \text { where }(\alpha+\beta+\gamma)<1
\end{aligned}
$$

The growth rate of the labor force is set as $\mathrm{L}_{(\mathrm{t})}=\mathrm{L}_{(0)} \mathrm{e}^{\mathrm{n}}{ }_{\mathrm{t}}$. Thus, the growth rate of the working population is constant $\frac{L}{L}=n$. It is also assumed that the overall function of the productivity evolves according to the function $\mathrm{A}_{(\mathrm{t})}=\mathrm{A}_{(0)} \mathrm{e}^{\dot{\omega}}$ where $\omega$ is the technological progress growth rate. Here $(\alpha+\beta+\gamma)<1$, that is, in other words, the recipe is supposed to decrease the capital.

Now the intensive form of the production function can be written as below:

$\mathrm{Y}(\mathrm{t})=\mathrm{k}(\mathrm{t})^{\alpha} \mathrm{h}(\mathrm{t})^{\beta} \mathrm{g}(\mathrm{t})^{\gamma}$

Where,

$y(t)=\frac{Y(t)}{A(t) L(t)}, k(t)=\frac{K(t)}{A(t) L(t)}, h(t)=\frac{H(t)}{A(t) L(t)}$ and $g(t)=\frac{G(t)}{A(t) L(t)}$

Represents the level of income per effective unit of labor, the physical capital per effective unit of labor and so on. Note that $S_{k}$, $S_{h}$ and $S_{g}$ are the shares of income invested in physical, human and public capital. Thus, changes in the physical, human and governmental capital through the effective working unit can be stated as follows:

$\mathrm{K}(\mathrm{t})=\mathrm{S}_{\mathrm{k}} \mathrm{y}(\mathrm{t})-\left(\mathrm{n}+\dot{\omega}+\delta_{\mathrm{k}}\right) \mathrm{k}(\mathrm{t})$

$\mathrm{H}(\mathrm{t})=\mathrm{S}_{\mathrm{h}} \mathrm{y}(\mathrm{t})-(\mathrm{n}+\dot{\omega}+\delta \mathrm{h}) \mathrm{h}(\mathrm{t})$

$\mathrm{G}(\mathrm{t})=\mathrm{S}_{\mathrm{g}} \mathrm{y}(\mathrm{t})-(\mathrm{n}+\dot{\omega}+\delta \mathrm{g}) \mathrm{g}(\mathrm{t})$

The involvement of equations (4), (5) and (6) is that all the capital that in effective unit labor converges towards a stationary value. Simpler than that, we assume $\delta=\delta_{\mathrm{k}}=\delta_{\mathrm{h}}=\delta_{\mathrm{g}}$, which means that the depreciation rate is the same for all capitals. Using the equations (4), (5) and (6) we can see that the economy converges towards a state of equilibrium and can be defined as follows:

$\mathrm{K}^{*}=\left(\frac{\mathrm{S}_{\mathrm{k}}^{1-\beta-\gamma} S_{\mathrm{h}}^{\beta} \mathrm{S}_{\mathrm{g}}^{\gamma}}{\mathrm{n}+\dot{\omega}+\delta}\right)^{1 /(1-\alpha-\beta-\gamma)}$
$\mathrm{h}^{*}=\left(\frac{\mathrm{S}_{\mathrm{h}}^{1-\alpha-\gamma} S_{\mathrm{k}}^{\alpha} S_{\mathrm{g}}^{\gamma}}{\mathrm{n}+\dot{\omega}+\delta}\right)^{1 /(1-\alpha-\beta-\gamma)}$

$\mathrm{g}^{*}=\left(\frac{\mathrm{s}_{\mathrm{g}}^{1-\alpha-\beta} \mathrm{S}_{\mathrm{k}}^{\alpha} \mathrm{S}_{\mathrm{h}}^{\gamma}}{\mathrm{n}+\dot{\omega}+\delta}\right)^{1 /(1-\alpha-\beta-\gamma)}$

The equations (7), (8) and (9) indicate that at the equilibrium state, the capital rise is in an increasing level of savings and decreasing with higher rates of the population growth.

When substituting the equations (7), (8) and (9) to the production function and taking the natural $\log$, the following equation of per capita income is obtained:

$\ln \left\{\frac{\mathrm{Y}(\mathrm{t})}{\mathrm{L}(\mathrm{t})}\right\}=\ln \left(\mathrm{A}_{0}\right)+\omega^{\prime} \mathrm{t}-\left[\left\{\frac{(\alpha+\beta+\gamma)}{(1-\alpha-\beta-\gamma)}\right\} \ln \left(\mathrm{n}+\omega^{\prime}+\delta\right)\right]+$ $\left\{\frac{\alpha}{1-\alpha-\beta-\gamma}\right\} \ln \left(\mathrm{S}_{\mathrm{k}}\right)+\left\{\frac{\beta}{(1-\alpha-\beta-\gamma)}\right\} \ln \left(\mathrm{S}_{\mathrm{h}}\right)+\left\{\frac{\gamma}{(1-\alpha-\beta-\gamma)}\right\} \ln \left(\mathrm{S}_{\mathrm{g}}\right)$

The model (10) does not provide a deep understanding of the economic growth. There are several other factors that can have an 
effect on the economic growth of a country. For example, North (1990) argued that the institutions of a country determine its longterm economic performance. Here, the institutions refer to the political stability, the quality of government, the independent judiciary, the political rights, the property rights, etc. So it is possible to change the model of economic growth above according to how these issues which can also have an impact on the development of a country.

Indeed, in the recent past, many researchers have studied the impact of several institutional dimensions, both theoretically and empirically. Many of them have taken the level of corruption or the level of control of corruption as a measure of evaluating the performance of the public institutions.

Corruption can directly affect the per capita income or growth, by affecting the total factor of the productivity of the country. In addition, corruption affects the growth indirectly by affecting the physical capital investment, the investments of the human capital and the public sector..

Thus, the model below explains how corruption has a direct impact on per capita income. It shows that corruption has a direct impact on growth by changing the overall productivity of the economy:

$$
\begin{aligned}
& \ln \left\{\frac{\mathrm{Y}(\mathrm{t})}{\mathrm{L}(\mathrm{t})}\right\}=\ln \left(\mathrm{A}_{0}\right)+\omega^{\prime} \mathrm{t}-\left[\left\{\frac{(\alpha+\beta+\gamma)}{(1-\alpha-\beta-\gamma)}\right\} \ln (\mathrm{n}+\omega+\delta)\right]+ \\
& \left\{\frac{\alpha}{1-\alpha-\beta-\gamma}\right\} \ln \left(\mathrm{S}_{\mathrm{k}}\right)+ \\
& \left\{\frac{\beta}{(1-\alpha-\beta-\gamma)}\right\} \ln \left(\mathrm{S}_{\mathrm{h}}\right)+\left\{\frac{\gamma}{(1-\alpha-\beta-\gamma)}\right\} \ln \left(\mathrm{S}_{\mathrm{g}}\right)-\eta \theta
\end{aligned}
$$

If the level of corruption is high according to the corruption index $(\theta)$, it can reduce the per capita income. A positive value of $\eta$ implies that corruption decreases the output per worker and vice versa.

This study covered a sample of 12 MENA countries over the period of 1998-2011. The Solow augmented Mankiw-Romer-Weil (MRW) model is used as a basis for this study. The production function incorporating the size of the government and the corruption is of the Cobb-Douglas form. By taking log, the linearized production function can be given as follows:

$$
\begin{aligned}
& \ln \left(\mathrm{Y}_{\mathrm{it}}\right)=\alpha_{\mathrm{i}}+\beta_{1} \ln \left(\mathrm{H}_{\mathrm{it}}\right)+\beta_{2} \ln \left(\mathrm{L}_{\mathrm{it}}\right)+\beta_{3} \ln \left(\mathrm{K}_{\mathrm{it}}\right)+ \\
& \beta_{4} \mathrm{CPI}_{\mathrm{it}}+\beta_{5} \ln \left(\mathrm{SIZE}_{\mathrm{it}}\right)+\mu_{\mathrm{it}}
\end{aligned}
$$

Where the subscript $\mathrm{i}=1, \ldots . ., \mathrm{N}$ denotes the country (in our study, we have 12 countries) and $t=1, \ldots \ldots, \mathrm{T}$ denotes the time period (our time frame is 1990-2011), $\alpha_{\mathrm{i}}$ is the individual specific effect and $\mu$ it is the error term. $\ln Y$ is real output, $\ln K$ is capital stock as proxies by the gross capital formation (\% of GDP) because it considered the inventory change. $\operatorname{lnL}$ is the working capital as measured by the rate of participation in the total labor force (\% of total population aged 15 and over). $\mathrm{H}$ is the human capital as a proxy enrollment in secondary schools (gross). CPI is the index of perception of corruption. Furthermore, we include the government size lnSIZE measured by the general government final consumption expenditures (\% of GDP) from the World Development Indicators in 2011. La Porta et al. (1999) find that countries with a bigger government are less corrupted; since the government size reflects greater law enforcement machinery and greater checks (see also Goel and Nelson (2010)).

To investigate the possibility of using the panel data, a specification test verifies that the model is perfectly identical for all countries or on the contrary each country has its own specificities: It tests the null hypothesis of the non-homogeneity. Using Fisher test, the $\mathrm{P}$-value for the statistic test $\mathrm{P}$-value $<5 \%$, which means that the null hypothesis can be rejected and the panel data specification can be accepted. " $F=101,87$ and Prob $>F=0,0000 "$ confirms that the model of homogeneity for our sample, which is also justified by the Standard deviation that of descriptive statistics in Table 1.
Table1: Descriptive Analysis

\begin{tabular}{lllll}
\hline Variables & Mean & Standard deviation & Minimum & Maximum \\
\hline Ln (GDP) & 8.378967 & 0.9021387 & 7.145039 & 10.13888 \\
CPI & 3.898425 & 1.106832 & 1.8 & 6.3 \\
Ln (SIZE) & 2.785205 & 0.3466381 & 1.750472 & 3.417865 \\
Ln (H) & 4.426759 & 0.2136841 & 3.595121 & 4.711163 \\
Ln (K) & 3.14953 & 0.3108888 & 2.067521 & 3.843744 \\
Ln (L) & 3.919093 & 0.1533098 & 3.691376 & 4.258446 \\
\hline
\end{tabular}

This analysis, data from 12 countries in the MENA region for the period that lies between 1998 and 2011 was performed by the STATA 11 software, based on the static panel data with a fixed effect after the test performed by Hausman (1978).

\subsection{Data}

To realize our research, we used several databases in a few countries in the MENA region and covering the 1998-2011 study periods. The countries covered by this study are twelve (12), chosen on the basis of availability of information on the indicators used during the period. We use two sets of data: Measures of corruption, measures of the size of government and macroeconomic data. The first database is the Transparency International where we extracted data from the index of perception of corruption (CPI) which indicates the perceived level of corruption in the public administration and the political class in the country. It is a composite index based on ten different surveys which are conducted among companies and experts. The vast majority of countries assessed, achieves a score less than 5 on a scale of 0 (high levels of perceived corruption) to 10 (highly corrupt). The second database is that of the World Bank that provides information on both the proxy of the size of government and those of the human capital, physical capital and working capital, both in terms of the real GDP reflecting the level of economic development.

\subsection{Sample}

For our sample, many reasons motivate the choice of some countries in the MENA region, among these causes we do not find much work that has brought on the relationship between corruption and economic growth for the region. As Bhattacharya and Wolde (2010) showed that, the MENA region as a whole had the lowest performance of the real per capita growth in all regions of the world. The neoclassical growth literature (especially Solow and Swan, 1956) has long emphasized the importance of the accumulation of the physical capital, the changes in the availability of labor and the exogenous technological progress in economic growth (both short and long term). More recently, the theory of the endogenous growth has made it clear that other variables such as investment in the human capital, the population dynamics, the institutions and the government's spending also play an important role in the increase of the population's wealth and the standard of living.

\section{Results and interpretations}

\subsection{Results}

We try to show the impact of the corruption and the size of gov-

\begin{tabular}{|c|c|c|}
\hline Variables & Fixed effect & Random effect \\
\hline Constant & $9.029352 * * *$ & $4.500576^{* * *}$ \\
\hline CPI & $-0.0479979 * *$ & -0.0217194 \\
\hline $\operatorname{Ln}(\mathrm{SIZE})$ & $-0.2888434 * *$ & $-0.2532774 * * *$ \\
\hline $\operatorname{Ln}(\mathrm{H})$ & $0.3860082 * * *$ & $0.4938994 * * *$ \\
\hline $\operatorname{Ln}(\mathrm{K})$ & $0.179197 * * *$ & $0.1596298 * *$ \\
\hline $\operatorname{Ln}(\mathrm{L})$ & -0.5223615 & 0.5066227 \\
\hline Hausman test (p-value) & & 00 \\
\hline
\end{tabular}
ernment on the economic growth: we take the case of the developing-countries. The Hausman test shows what method, we must remember. The estimation result is presented in the table below.

Table 2: Static Panel Data 
$* * *$ Coefficient significantat $1 \%$ level, **Coefficient significantat5\%level *Coefficient significantat $1 \%$ level.

\subsection{Interpretations and policy implications}

In the context of our model (Eq12), the implementation of the Hausman test in STATA 11 software gives us the following results: the p-value (Prob $>$ chi $2=0.00 \leq 0.05$ ), so the test leads to accept the model with fixed effects against the random effects model.

Our results show a significant negative effect of the government size on the economic growth, this result is supported by Afonso, Sckuknecht and Tanzi (2003) who found that countries with a small public sector appear to be more effective, it is also supported by Becker (2008) who also showed that countries with clear regulations, are close to the citizens who are directly related to their political goals and are relatively efficient in their spending. Interestingly, the government is consumption is always detrimental to the growth of production and the negative effect of government size on the real GDP is stronger at lower levels of the institutional quality.

The majority of studies lying on the relationship between government size and economic growth pointed out a negative impact of the former on the latter, taking as an example the documents linked by Bergh and Karlsson (2010) and Afonso and Jalles (2011) who found that the size of government is negatively correlated with growth.

Public spending, especially those which are allocated to government is consumption, are a very important part of all government spending. Such spending can increase the perception of corrupted administrators and can reduce the economic growth. According to Park et al. (2005), if public spending is subject to the rent-seeking, then there are losses in the economic growth. Lal (1985) points out the misallocation of resources by a government, and social scientists such as Mills (1986) argue that government failure is more problematic than a market failure. Government size can also be viewed as the number of bureaucrats and/or their expenses, such as wages and salaries. Niskanen (1971) defines government bureaucrats as agents seeking to maximize the size of their budgets and points out that they have no incentive to be efficient.

There are common themes in MENA countries to the challenges posed by the fight against corruption. The revolutions that have raised the Middle East and North Africa (MENA) in 2011 revealed the omnipresent corruption, particularly in the political sphere, in the form of allegedly stolen assets by all the fallen leaders. Many items also attest to the existence of the widespread practices such as favoritism, nepotism and collusion between the public and private sector. These practices have contributed to a growing social unrest and public protests in the region. The index of perception of corruption by Transparency International shows that the level of corruption is very high in many countries in the region, compared with the world average.

This response will focus more specifically on Egypt, Jordan, Libya, Morocco and Tunisia. Each country has specific political, social and economic characteristics that create specific challenges to overcome corruption. Egypt, Libya and Tunisia, in particular, have all experienced in recent years a change in regime as a result of the revolts citizens. These changes offer promising opportunities for political reform and restructuring of the legal and institutional framework to strengthen the public integrity.

Statistically, the variable of corruption has a significant negative impact on the economic growth in our sample; this result strengthens the idea, of Avnimelech and Zelekha (2011), also Blackburn et al. (2008), that corruption is leading to an increase in inflation, which in turns reduces the capital accumulation and the economic growth. In the same idea, Gerlagh Pellegrini (2004) studied the effect of corruption on the economic growth, both directly and through its impact on investment, schooling, trade openness and political instability. Their results show that corruption has a negative effect on the economic growth. For Tanzi and Davoodi (2000), Johnson, and Yamarik La Fountain (2011), corruption undermines growth because it has a negative impact on both the quantity and the quality of the public investment. It erodes the efficiency of the public investment decisions, particularly because it induces a preference for major projects which are likely to generate significant private gains for policy makers. This result reinforces the idea that Collier (2000) shows that in an environment of high corruption that companies can benefit from government subsidies and thus, they affect the efficiency of the public spending. This is the reason why, corruption is revealed as a brake on the economic growth through the spending and therefore the size of government. Based on the augmented Solow model, the variable of the physical capital is positively related to economic growth, the same remains true for Chen and Fleisher (1996), Gundlach (1997), Li et al. (1998) and Choi and $\mathrm{Li}$ (2000), Henderson et al. (2007) which allows us to say that the physical capital appears to have a key role for the economic growth in the MENA region. As told one of the main architects of the "new growth theory" Paul Romer (1986); "It is important to note that the increase in the available capital contributes directly to growth by increasing production capacity and, indirectly by its contribution to the incorporation of technological progress in the production process. It is this aspect that attracts the attention of the theory of endogenous growth. This is a first example of the role of externalities in growth."

Our results show that the variable of the human capital is proxies by the enrollment in secondary schools which is important in determining growth. Our results confirm those of several empirical studies highlighting the importance of this factor (Barro, 1991; Levine \&Renelt, 1992; Mankiw et al, 1992; Fleisher \& Chen, 1997; Wang and Yao, 2003; Altinok, 2006; H. Li \& Huang, 2009; $\mathrm{Li}$ and Liu, 2011), also strengthens the idea of Krueger and Lindahl (2001) who have shown that human capital is positively and significantly linked to the growth in for countries which have a low level of education. According to Romer (1986) "physical capital and human capital has a dual contribution to growth by adding arms indirectly through the dissemination of ideas. This is another aspect of the role of externalities in growth. "

The coefficient of the variable "working capital" is negative and not significant. It statistically indicates a lack of association between this variable and economic growth of these countries, which is justified by the low productivity of labor in the MENA region.

\section{Conclusion and recommendations}

The present study investigates the linkages between government size, corruption and economic growth using the Cobb-Douglas production function. While the literature on the relation between these three phenomena has increased over the last few years, the objective of the present study is to examining the above interaction for 12 MENA countries over the period 1998-2011.

The results have shown that the public spending, especially those which are allocated to the government's consumption are a very important part of all government' spending. Such spending can increase the perception of the corrupted administrators and can reduce the economic growth. Corruption also reveals itself as an obstacle to the economic growth through the spending and therefore the size of government.

The main contribution in this paper is to demonstrate the increasing size of government which creates more opportunities for rentseeking and corruption. By the latter the amount of output provided and the quality of projects invested by the state, find a significant reduction.

So, to achieve further economic growth and development, it is important to efficiently utilize funds which are plundered and/or used inefficiently by corruption. Although government intervention can remedy market failures and play an important role in economic development, it can lead to an increase in government size. The results indicate that good governance can improve growth outcomes. Therefore in conclusion it can be stated that public spending is a necessary but not sufficient condition for 
economic growth and the good governance can improve growth outcomes.

An implication from our study is that in order to utilize the government's intervention role without increasing corruption, countries should promote good governance to accelerate their growth rates.

\section{References}

[1] Abu-Bader, S., \& Abu-Qarn, A. S. (2003). Government expenditures, military spending and economic growth: causality evidence from Egypt, Israel, and Syria. Journal of Policy Modeling, 25(6), 567-583.

[2] Acemoglu, D., \&Verdier, T. (2000). The choice between market failures and corruption. American economic review, 194-211.

[3] Ahlin, C., \& Pang, J. (2008). Are financial development and corruption control substitutes in promoting growth? Journal of Development Economics, 86(2), 414-433.

[4] Aidt, T., Dutta, J., Sena, V. (2008), "Governance Regimes, Corruption and Growth: Theory and Evidence", Journal of Comparative Economics, Vol. 36, pp. 195-220.

[5] Aidt, Toke S. (2009), "Corruption, Institutions and Economic Development", Oxford Review of Economic Policy, Volume 25, Number 2, 2009, pp.271-291.

[6] Bajo-Rubio, O. (2000), "A further Generalization of the Solow Growth Model: the Role of the Public Sector," Economics Letters, $68,1,79-84$.

[7] Barro, R. (1991), Economic growth in a cross section of countries. The quarterly journal of economics, 407-443.

[8] Bergh, A., Karlsson, M., (2010). Government size and growth: accounting for economic freedom and globalization. Public Choice 142 (1), 195-213.

[9] Brunetti, A., \&Weder, B. (2003). A free press is bad news for corruption. Journal of Public Economics, 87, 1801-1824.

[10] Cooray A, (2009). Government Expenditure, Governance and Economic Growth. Comparative Economic Studies, 51(3): 401-418.

[11] De Vaal, A., W., Ebben, (2011), "Institutions and the relation between corruption and economic growth". Review of Development Economics 15 (1), 108-123.

[12] Devarajan S., Swaroop V., Zou H. (1996). The composition of public expenditure and economic growth, Journal of Monetary Economics, Vol. 37, pp. 313-344.

[13] Easterly, W, Sergio, R (1993). "Fiscal policy and economic growth An empirical investigation," Journal of Monetary Economics, Elsevier, 32(3), 417-458.

[14] Ehrlich, I., \& Lui, F. T. (1999). Bureaucratic corruption and endogenous economic growth. Journal of Political Economy, 107(S6), 270-S293.

[15] Fatas, A., J. von Hagen, A. Hughes Hallet, A. Siebert, R. R. Strauch (2003). Stability and Growth in Europe: Towards a Better Pact, Centre for Economic Policy Research.

Fleisher, B., Chen, J. (1997). The coast-non coast income gap, productivity, and regional economic policy in China. Journal of Comparative Economics, 25, 220-236.

[16] Folster S, Henrekson M, (2001). Growth Effects of Government Expenditure and Taxation in Rich Countries. European Economic Review, Vol. 45, No. 8, pp 1501-1520.

[17] Ghali, K.H., (1998). Government size and economic growth: evidence from a multivariate co integration analysis. Applied Economics 31, 975-987.

[18] Guseh, J. S. (1997) "Government Size and Economic Growth in Developing Countries: A Political-Economy Framework”. Journal of Macroeconomics 19(1), 175-192.

[19] Huynh, K.1., Jacho-Chavez, D.T, (2009). Growth and governance A non-parametric analysis. Journal of Comparative Economics, 37 (1), 121-143.

[20] Galí, J., \&Perotti, R. (2003). Fiscal policy and monetary integration in Europe.economic policy, 18(37), 533-572.

[21] JordiGalI,, Roberto Perotti, (2003). "Fiscal policy and monetary integration in Europe," Economic Policy, 18(37), 533-572.

[22] Landau, D. (1986). Government and economic growth in the less developed countries: an empirical study for 1960-1980. Economic Development and Cultural Change, 35(1), 35-75.

[23] Levine, R., Renelt, D. (1992). A sensitivity analysis of crosscountry growth regressions. The American Economic Review, 82, 942-963.
[24] Li, H., Huang, L. (2009). Health, education, and economic growth in China: empirical findings and implications. China Economic Review, 20, 374-387.

[25] Li, K. W., Liu, T. (2011). Economic and productivity growth decomposition: an application to post-reform China. Economic Modelling, 28, 366-373.

[26] Lu, Z.-L., Sperling, G. (2001). Three-system theory of human visual motion perception: Review and update. Journal of the Optical Society of America, 18, 2331-2370.

[27] Lucas, R. E. (1988). On the mechanics of economic development. Journal of Monetary Economics, 22, 3-42.

[28] Lui, F.T., (1985). An Equilibrium Queuing Model of Bribery. Journal of Political Economy 93, 760-781.

[29] Mauro, Paulo. (1995). Corruption and Growth. Quarterly Journal of Economics 110: 681-712.

[30] Mankiw, N., Romer, D., Weil, D. (1992). A contribution to the empirics of economic growth. The quarterly journal of economics, 107 407-437.

[31] Mo, Pak Hung (2001), "Corruption and Economic Growth", Journal of Comparative Economics, Vol. 29, pp.66-79.

[32] Ram, R. (1986). Government Size and Economic Growth: A New Framework and some Evidence from Cross-Section and TimeSeries Data. American Economic Review, 76(1), 191-203.

[33] Romer, P.M. (1986). Increasing returns and long-run growth. Journal of Political Economy, 94, 1002-1037.

[34] Shleifer, A., Vishny, R.W., 1993. Corruption. Quarterly Journal of Economics 108, 599-617.

[35] Treisman, D. (2000). "The causes of corruption: a cross-national study." Journal of Public Economics; vol.76, n³, pp.399-457.

[36] Wang, Y., Yao, Y. (2003). Sources of China's economic growth 1952 ${ }^{\circ}$ 1999: incorporating human capital accumulation. China Economic Review, 14, 32-52.

[37] Zagler, M., Durnecker, G. (2003). Fiscal Policy and economic growth. Journal of Economic Surveys, 17 (3), 397-418. 